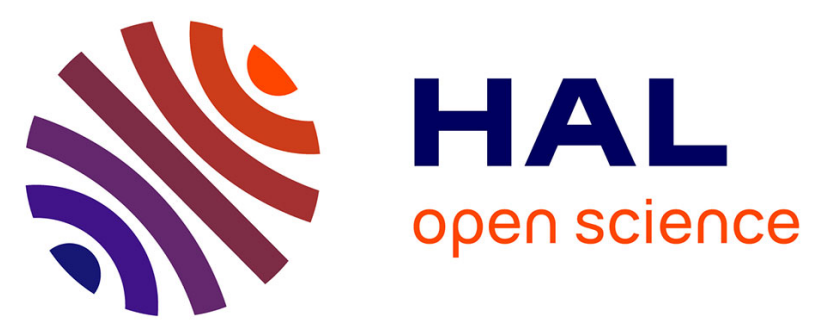

\title{
"The Torah Between Revelation and Concealment in Rabbinic Traditions Pertaining to the Conquest of the Land of Canaan"
}

Katell Berthelot

\section{- To cite this version:}

Katell Berthelot. "The Torah Between Revelation and Concealment in Rabbinic Traditions Pertaining to the Conquest of the Land of Canaan". Mladen Popović; Lautaro Roig Lanzillotta; Clare Wilde. Sharing and Hiding Religious Knowledge in Early Judaism, Christianity, and Islam, De Gruyter, pp.85-105, 2018, 978-3-11-059660-1. 10.1515/9783110596601-005 . hal-02338928

\section{HAL Id: hal-02338928 \\ https://hal.science/hal-02338928}

Submitted on 30 Oct 2019

HAL is a multi-disciplinary open access archive for the deposit and dissemination of scientific research documents, whether they are published or not. The documents may come from teaching and research institutions in France or abroad, or from public or private research centers.
L'archive ouverte pluridisciplinaire HAL, est destinée au dépôt et à la diffusion de documents scientifiques de niveau recherche, publiés ou non, émanant des établissements d'enseignement et de recherche français ou étrangers, des laboratoires publics ou privés. 


\section{The Torah Between Revelation and Concealment in Rabbinic Traditions Pertaining to the Conquest of the Land of Canaan}

\subsection{Introduction}

What religious knowledge is more crucial to the Jews than knowledge of the Torah? In a way, all religious knowledge can be considered Torah, at least according to rabbinic Judaism, which distinguishes between Written and Oral Torah, but views them as deeply united.

If one goes back to the biblical period, when the God of Israel was still conceived of as the God of a specific people as opposed to other peoples with their own "national" gods, the laws of Israel were simply the "national" laws of the Israelites, not a Law given as a Revelation to the entire world. However, after the Exile and with the evolution of Israel's religion toward monotheism, biblical laws started to be considered a universal Law, the Law of the one and only God, the Law of the God of the universe. ${ }^{1}$ During the Hellenistic and early Roman period, there were Jewish authors who formulated the idea that the Torah was in agreement and harmony with the Law of Nature, or with the Logos. ${ }^{2}$ Knowledge of the Torah could therefore be achieved through the use of one's logos, or reason, just as knowledge of God could be achieved through contemplation of the cosmos.

1 The literature on this topic is extensive. See for instance Sidney Greidanus, "The Universal Dimension of Law in the Hebrew Scriptures," Studies in Religion/Sciences Religieuses 14/1 (1985): 39-51.

2 This is particularly clear in the work of Philo of Alexandria. See Carlos Lévy, Cicero academicus: Recherches sur les “Académiques” et sur la philosophie cicéronienne (Rome: Ecole française de Rome, 1992), 516-20; John W. Martens, One God, One Law: Philo of Alexandria on the Mosaic and Greco-Roman Law (Boston - Leiden: Brill, 2003); Hindy Najman, "A Written Copy of the Law of Nature: An Unthinkable Paradox?” The Studia Philonica Annual 15 (2003): 54-63; Gregory E. Sterling, "Universalizing the Particular: Natural Law in Second Temple Jewish Ethics," The Studia Philonica Annual 15 (2003): 64-80.

Note: This research has been funded by the European Research Council (ERC) under the European Union's Seventh Framework Program (FP/2007-2013)/ERC Grant Agreement no. 614 424. It has been conducted within the framework of the ERC project JUDAISM AND ROME, under the auspices of the Centre national de la recherche scientifique (CNRS) and Aix-Marseille University, UMR 7297 TDMAM (Aix-en-Provence, France).

https://doi.org/10.1515/9783110596601-005 
This understanding of God and the Torah justified the sharing of religious knowledge between Jews and non-Jews.

Other groups within Judaism, however, saw it differently. The leaders of the communities described in some of the Dead Sea Scrolls could hardly share religious knowledge even with fellow Jews if the latter had not become members of their communities. As for the Palestinian rabbis, they were deeply ambivalent about the possibility of sharing the Torah with non-Jews. In the long run, the view according to which the Torah was given exclusively to Israel and was not meant to be taught to Gentiles or practiced by Gentiles became the majority view in rabbinic Judaism. This evolution was of huge significance for the history of Judaism as a whole.

However, in his book entitled Torah for the Entire World, Marc Hirshman has argued that within early rabbinic literature, there were still differing opinions. He has drawn attention to a group of early rabbinic writings that convey what he calls a universalistic understanding of the Torah, according to which it was offered not only to Israel, but to all human beings. According to Hirshman, this universalistic trend is connected to the school of Rabbi Ishmael, a rabbi from the second century $\mathrm{CE}^{3}$ A famous example of such a universalistic trend is found in the midrash (or commentary) on the Book of Exodus called Mekhilta deRabbi Ishmael, the final redaction of which dates from the third century CE. In connection with Exodus 19:2, "They (Israel) encamped in the wilderness," the midrash states that:

The Torah was given publicly (Heb. dèmos, from Greek $\delta \tilde{\eta} \mu \circ \varsigma$ ), openly (Heb. parrēsia, from Greek $\pi \alpha \rho \rho \eta \sigma^{\prime} \alpha$ ), in a free place. For had the Torah been given in the Land of Israel, (the Israelites) would have said to the nations of the world, 'You have no share in it'. ${ }^{4}$ Therefore it was given in the wilderness publicly, openly, in a free place, (so that) everyone wishing to accept it, (could) come and accept it. ${ }^{5}$

As Hirshman notes, "It is striking that the Mekilta not only advanced the claim that revelation had been intended for all peoples, but did so in a vocabulary that

3 See Marc (Menahem) Hirshman, Torah for the Entire World (Tel Aviv: Hakibbutz Hameuchad, 1999); idem, "Rabbinic Universalism in the Second and Third Centuries," Harvard Theological Review 93 (2000): 101-15.

4 With a small correction to the edition of Horovitz-Rabin, 205, which has: אין להם ("They do not have a share...”). MS Oxford 151 has אין לכם. This is merely an issue of direct versus indirect speech.

5 MRI Bahodesh 1. See Horovitz-Rabin, 205; the translation is based on that of Jacob Z. Lauterbach, Mekhilta de-Rabbi Ishmael: A Critical Edition, Based on the Manuscripts and Early Editions, with an English Translation, Introduction, and Notes, 2nd ed. (Philadelphia: The Jewish Publication Society, 2004), 2:293-295, slightly modified. MS Oxford 151 omits the word oומד in the first sentence, but it is found in the second. 
was the hallmark of Greco-Roman democracy."6 One ought to be more precise, however. The words dèmos and parrēsia can actually be considered to refer to two different phenomena in the Roman world: on the one hand, the publication of a law demos(ia), "in a public place" recalls the norms by which laws, edicts or official letters had to be published in the Roman Empire ${ }^{7}$; on the other hand, the Greek term parrēsia, "boldness, freedom of speech," is reminiscent of the Stoic philosophers who opposed the Roman emperors, with the implication that God is put in the role of a philosopher who boldly tells the truth to the world. In both cases, one could not be further away from an expression of religious esotericism.

In the following lines of the midrash, Rabbi Yose emphasizes this point by quoting God's words in Isa 45:19 ("I have not spoken in secret, in the place of a land of darkness" etc.) and by rephrasing the divine speech as follows: "When I gave (the Torah) from the very start, I did not give it in secret, neither in the place of a land of darkness, nor in an obscure place." This means that God did not reveal the Torah to Israel alone, but wanted to share it with all the nations. However, the latter refused to receive it. ${ }^{8}$

Another early rabbinic (Tannaitic) midrash, the Sifre Deuteronomy, declares that God did not reveal the Torah in merely one language, but in four languages, Hebrew, "Roman" (romi, meaning Latin), Arabic and Aramean. ${ }^{9}$ Moreover, the midrash goes one step further and states that God did not reveal the Torah to Israel alone, but to all the nations (umot). The latter, however, declined God's offer, because they did not want to repent from their wicked ways.

In the end, in both Mekhilta deRabbi Ishmael, traditionally linked to the school of Rabbi Ishmael, and Sifre Deuteronomy, traditionally linked to the school of Rabbi Akiva, the nations are condemned for not having accepted the Torah, and both midrashim foretell their forthcoming judgement. ${ }^{10}$

6 Hirshman, "Rabbinic Universalism in the Second and Third Centuries," 103.

7 See Katell Berthelot, "Rabbinic Universalism Reconsidered: The Roman Context of some Rabbinic Traditions pertaining to the Revelation of the Torah in Different Languages," forthcoming in Jewish Quarterly Review 108.4 (2018). On the Roman norms for the publication of official documents, see Fritz F. Von Schwind, Zur Frage der Publikation im römischen Recht, Münchener Beiträge zur Papyrusforschung und Antiken Rechtsgeschichte 31 (Munich: Beck, 1940), esp. 84, 86; Clifford Ando, Imperial Ideology and Provincial Loyalty in the Roman Empire (Berkeley: University of California Press, 2000), 80-101.

8 See MRI Bahodesh 1, ed. Horovitz-Rabin, 206.

9 Sifre Deuteronomy 343 on Deut 33:2; see ed. Finkelstein, 395-97 for the whole argument. 10 See MRI Bahodesh 1 (after the passage quoted above; ed. Horovitz-Rabin, 206): "R. Eliezer the son of R. Jose the Galilean used to say: Behold it says: He declares His word to Jacob ... He has not dealt so with any other nation (Ps 147:19-20). But what had those wretched nations done that He would not give them the Torah? They do not know his ordinances (ibid.)-they were unwilling 
A straightforward conclusion would seem to be that after the episode at Sinai, the Torah was not meant to be shared with any nation at all, insofar as it had already been offered to the nations of the world, who had unanimously refused it and were now doomed. Other passages in rabbinic literature, however, tell us that the Torah was once again made known to the nations after the Israelites had arrived in Canaan. The idea that the Torah was made known to the Canaanites is highly paradoxical, and contradicts the instructions given to the Israelites in the Bible, which were either to expel or to eradicate the inhabitants of the Land. Nowhere in the Torah is it stated that these nations could repent from their idolatry and their abominations; nowhere are the Israelites supposed to try to convert them to the ways of YHWH. They must simply get rid of them. The rabbinic passages I am alluding to, however, suggest that the Torah was revealed to them and that their fate could have been utterly different. Sharing the Torah with the Canaanites could have led to their inclusion instead of their exclusion.

We shall see that these rabbinic texts actually refer to both the revelation and the concealment of the Torah. In order to understand the logic behind the texts, we first need to go back to the Hebrew Bible and look at a peculiar commandment given by Moses to Joshua and Israel slightly before the conquest. I shall then analyse each rabbinic text and its specific rhetorical strategy separately, in order to show how the argumentation developed from text to text, and to clarify the exegetical, theological and ethical issues at stake in sharing or not sharing knowledge of the Torah with the Gentiles. Finally, I shall try to draw a connection between these texts and the historical context in which they were written, that of the Roman Empire and the attempt by the rabbis to resist imperial domination.

to accept them, as it is said: God comes from Teman ... and a brightness appears as the light ... before Him goes the pestilence ... He stands, and shakes the earth, He beholds, and makes the nations to tremble, etc. (Hab 3:3-6)" (trans. Lauterbach, Mekhilta de-Rabbi Ishmael, 2:295). In Sifre Deuteronomy 343, one reads: "And so (God) asked every nation individually whether they wanted to accept the Torah, as it is said: All the kings of the earth shall praise you, O Lord, when they hear the words of your mouth (Ps 138:4). Could it be that they heard and accepted? Scripture says: And I will execute vengeance in anger and fury upon the nations, such as they have not heard (Mic 5:14). It was not enough for them not to hear [the Torah], even the seven commandments that the children of Noah accepted [to take] upon themselves they were unable to keep" (ed. Finkelstein, 396; my translation). 


\title{
4.2 The Biblical Traditions Concerning the Transcription of the Torah Upon the Stones (Deut 27:2-8; Jos 4:1-24; Jos 8:30-34)
}

The commandments formulated in Deuteronomy 27:2-8 are as follows:

\begin{abstract}
2 And on the day you pass over the Jordan to the land which the Lord your God gives you, you shall set up large stones, and plaster them with plaster; 3 and you shall write upon them all the words of this Law (Torah), when you pass over to enter the land which the Lord your God gives you, a land flowing with milk and honey, as the Lord, the God of your fathers, has promised you. 4 And when you have passed over the Jordan, you shall set up these stones, concerning which I command you this day, on Mount Ebal, and you shall plaster them with plaster. 5 And there you shall build an altar to the Lord your God, an altar of stones: you shall lift up no iron tool upon them. 6 You shall build an altar to the Lord your God of unhewn stones; and you shall offer burnt offerings on it to the Lord your God; 7 and you shall sacrifice peace offerings, and shall eat there; and you shall rejoice before the Lord your God. 8 And you shall write upon the stones all the words of this law very plainly (ba'er heyțev) (trans. NRSV).
\end{abstract}

The wording of this text is highly ambiguous. Verses 2 and 4 seem to repeat each other: one wonders whether large stones are to be erected twice, first immediately after the crossing of the Jordan and then again on Mount Ebal, or whether the text refers to the same stones. If the text refers to the same stones, are they to be plastered twice, and, in this case, would the second plaster not cover the words of the Law? Finally, what about the stones of the altar? Does verse 8 mean that the Law is to be written upon the stones of the altar as well? Or is it simply summarizing the commandment given in this passage? In short, this text is replete with ambiguities.

The account of the Book of Joshua, which supposedly describes how the conquest happened, clarifies these issues only to a certain extent. Chapter 4 tells the story of the miraculous crossing of the Jordan River by Israel. The Israelites pick up twelve stones in the bed of the river and Joshua has the stones (steles) erected at Gilgal, as a memorial for future generations, who will thus remember the miracle performed by God for their ancestors, and as a testimony to all the peoples of the world (Josh 4:24). However, these stones are not plastered with plaster and can hardly be identified with the stones mentioned in Deuteronomy 27. In the Book of Joshua, the commandment of Deuteronomy 27 is performed at a later stage, on Mount Ebal, together with the construction of the altar (Joshua 8:30-35). ${ }^{11}$

11 "30 Then Joshua built an altar in mount Ebal to the Lord, the God of Israel, 31 as Moses the servant of the Lord had commanded the people of Israel, as it is written in the book of the 
We read in Joshua 8:32: "And there, in the presence of the people of Israel, he wrote upon the stones a copy of the law of Moses which he had written" (trans. NRSV). It seems that in this case, the stones on which the Torah was written are those of the altar, mentioned in the previous verses. But there is no reference to the plaster. Thus, when all the biblical passages related to the stones, the transcription of the Torah and the memorial are taken together, some contradictions or unclear points remain.

\subsection{Mishnah Soțah 7:5}

In rabbinic literature, the story of the stones on which the Torah was written is first referred to briefly in the Mishnah, tractate Soțah, at the end of a section that deals with the blessings and curses to be pronounced by Israel on Mount Garizim and Mount Ebal (Deut 27-28, Josh 8:30-35):

And afterward they brought the stones and built the altar and plastered them [the stones] with plaster. And they wrote upon them all the words of this Law [in] seventy languages, as it is written, very plainly (ba'er heytev; Deut 27:8). And they took the stones and came and spent the night in their own place. ${ }^{12}$ (M. Soțah 7:5)

The Mishnah seems to imply that the Torah was written on the stones of the altar, as in the Book of Joshua. The biblical passage referred to, however, is Deuteronomy 27:8, while the idea that the Israelites brought the stones (those taken from the midst of the Jordan) in the place where they were about to spend the night comes from Joshua 4:3 and 8 (the context of which refers to the stones taken from the midst of the Jordan river).

\footnotetext{
law of Moses, 'an altar of unhewn stones, upon which no man has lifted an iron tool'; and they offered on it burnt offerings to the Lord, and sacrificed peace offerings. 32 And there, in the presence of the people of Israel, he wrote upon the stones a copy of the law of Moses, which he had written. 33 And all Israel, sojourner as well as homeborn, with their elders and officers and their judges, stood on opposite sides of the ark before the Levitical priests who carried the ark of the covenant of the Lord, half of them in front of Mount Gerizim and half of them in front of Mount Ebal, as Moses the servant of the Lord had commanded at the first, that they should bless the people of Israel. 34 And afterward he read all the words of the law, the blessing and the curse, according to all that is written in the book of the law. 35 There was not a word of all that Moses commanded which Joshua did not read before all the assembly of Israel, and the women, and the little ones, and the sojourners who lived among them" (trans. NRSV, 272-73).
}

12 MS Kaufmann, the translation is mine. 
The context of this mishnah is a discussion starting in Mishnah Sotah 7:1 about the prayers or texts that may be recited in any language and those that must be recited in Hebrew. ${ }^{13}$ Among the latter are "the paragraph of the first-fruits, the words of halitzah, the Blessings and the Cursings [the passage immediately following the one concerning the stones, Deut 27:12-28:68], the Blessings of the priests and the Blessings of the high priest, the paragraph of the king, the paragraph of the heifer whose neck is to be broken, and [the words of] the Anointed for battle when he speaks unto the people." ${ }^{4}$ This list is based on a typically rabbinic hermeneutical principle, according to which cases mentioned in different biblical verses are associated with each other because these verses share a similar formulation. In this mishnah, the essential feature is the combination of the verbs "answer" ('anah) and "say" ('amar) in the implied biblical verses, a combination that looks quite repetitive and superfluous.

Mishnah Sotah 7:1-5 thus states that the Blessings and Cursings in chapters 27-28 of Deuteronomy are to be recited in Hebrew, but on the other hand, building upon Deuteronomy 27:8, it understands the expression ba'er heytev, "very plainly," as referring to the translation of the Torah in seventy languages. What does it mean? The number seventy is highly symbolic and means that the Torah was translated into all the languages of humankind. It may imply that the Torah was communicated to the nations, but not necessarily so. As both Willem Smelik and Steven Fraade have argued, if one looks at this mishnaic passage independently of the traditions found in the Tosefta and later rabbinic texts, the Mishnah's very brief statement can be understood to reflect a philosophy of language according to which the Torah had to be formulated in all the languages of the world in order for all the nuances of its meaning to be manifested. According to such an interpretation, the translation of the Torah was meant only for the Jews, or - if one follows Smelik's analysis - was not meant for anyone in particular. $^{15}$

13 On this section of the Mishnah, see Judith Hauptman, Rereading the Mishnah: A New Approach to Ancient Jewish Texts, Texts and Studies in Ancient Judaism 109 (Tübingen: Mohr Siebeck, 2005), 196-207. In this case she sees the Mishnah as a reworking of the parallel tradition in the Tosefta.

14 Trans. by Herbert Danby, The Mishnah (Oxford: Oxford University Press, 1933), 300.

15 See Willem Smelik, Rabbis, Language and Translation in Late Antiquity (Cambridge: Cambridge University Press, 2013), 29-30, who writes: "The Mishnah does not indicate that these translations were aimed at the nations-not even that they were aimed at Israel's enlightenment." See also (with some differences) Steven Fraade, "Before and After Babel: Linguistic Exceptionalism and Pluralism in Early Rabbinic Literature and Jewish Antiquity," Diné Israel 28

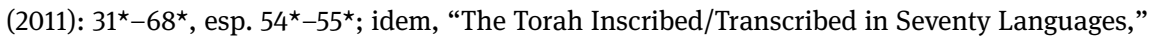
in Hebrew between Jews and Christians, ed. Daniel Stein Kokin, Studia Judaica (Berlin: De 
Whereas this interpretation is definitely a possibility, the other interpretation, that the translation was meant to communicate the Torah to the nations, also remains possible. In this case, the underlying idea would be that the Torah was made known to all the nations of the world, including the Canaanites. This point is reminiscent of the tradition found in the passage of the Mekhilta deRabbi Ishmael referred to in the introduction, and this mishnah has thus been associated with the school of Rabbi Ishmael. ${ }^{16}$ The Mishnah, however, does not clarify what the publication of the Torah in seventy languages implied for the Israelites' encounter with the Canaanites. We must look at the Tosefta for a slightly more detailed account.

\subsection{Tosefta Soțah 8:6-7}

The eighth chapter of tractate Sotah in the Tosefta deals with the crossing of the Jordan river by Israel on their way to the Land of Canaan, the instructions given to Israel by Joshua, the miracle of the waters that were cut off before the ark of the covenant, the twelve stones that were set up in the midst of the Jordan in the place where the feet of the priests who bear the ark stood (Josh 4:5), and the stones that were carried away from the midst of the Jordan (Joshua 4:3, 8, 20). In $\S \S 8: 6-7$, we encounter a different version of the tradition found in Mishnah Soțah 7:5:

R. Yehudah says: They wrote it [the Torah] on the stones of [the] altar. They told him: How did the nations of the world learn [the laws of] the Torah? He told them: This teaches that God inspired the heart of every nation and every kingdom, and they sent their scribes (notarim, from notarius in Latin), and they transcribed the text that stood on the back of the stones in seventy languages. On that very hour, the decree of the judgement of the nations of the world was sealed, [and they were doomed] to the pit of destruction.

R. Shimeon says: They wrote [the laws of the Torah] on the plaster. How? They panelled it [i.e., the altar] and plastered it with plaster, and they wrote on it all the words of the Torah in seventy languages. And at the bottom they wrote: That they may not teach them [or: you, as in $\mathrm{MT}$ ( to do according to all their abominable practices which they have done in the service of their gods) (Deut 20:18). If you repent from them, ${ }^{17}$ we shall receive [or: accept] you ${ }^{18}$ (T. Soțah 8:6-7)

Gruyter, forthcoming). Fraade considers that the translation was meant for Israel; the underlying implication could be that no matter where Jews would live and what language they would speak, access to the Torah would be possible for them.

16 See Hirshman, Torah for the Entire World, 110, 113. And see below for the analysis of the passage from Mekhilta Deuteronomy.

17 With a small correction (בהם instead of בהם).

18 The translation is mine and is based on the Hebrew text of MS Vienna 46, consulted on the website of the Academy of the Hebrew Language (Ma'agarim) (see also ed. Lieberman, 205, 
Whereas the tradition in the Mishnah was anonymous, here we have a discussion between two tannaim who lived in the second century CE, Rabbi Yehudah and Rabbi Shimeon. ${ }^{19}$ Both seem to rely on a tradition connected to the one found in the Mishnah, since both mention the seventy languages, but the nature of the relationship between the Mishnah and the Tosefta is unclear in this case. They could both rely on a common, previous tradition. ${ }^{20}$

R. Yehudah and R. Shimeon understand the biblical texts in different ways. The first point of divergence between them has to do with the technical details of the act of copying: Was the Torah written directly on the stones of the altar or on the plaster laid on the stones, which would have made the text much easier to read? While R. Yehudah defends the first option, R. Shimeon opts for the second. ${ }^{21} \mathrm{R}$. Yehudah seems to rely on a literal reading of Deuteronomy 27:8, "And you shall write upon the stones," whereas R. Shimeon seems to follow the wording and the sequence of actions found in Deuteronomy 27:2-3 - "you shall set up large stones, and plaster them with plaster, and you shall write upon them" - , which also seems to be the Mishnah's source of inspiration: “... they plastered them (the stones) with plaster. And they wrote upon them all the words of this Law ...."

A second divergence between the two sages may have to do with the language (or languages) in which the Torah was written on the stones. The statement of

which has a slightly different text; the overall meaning, however, remains the same):

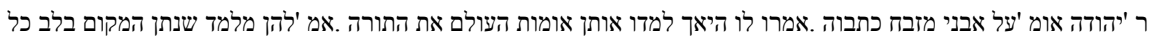

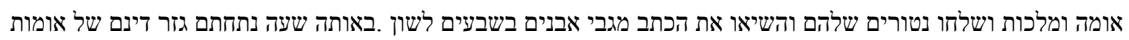
העולם לבאר שחת.

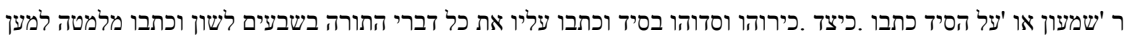

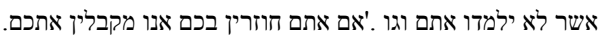

19 On R. Shimeon (ben or bar Yohai) and R. Yehudah (bar Ilai), who were students of R. Akiva, see Herman L. Strack and Günter Stemberger, Introduction to the Talmud and Midrash (Minneapolis: Fortress, 1996), 76-77.

20 This is the position of Steven Fraade (see the bibliographical references in note 15 above, especially "Before and After Babel," 55*). Judith Hauptman considers that "the redactor of the Mishnah reworked the Tosefta in order to make a number of points of his own," so that the mishnaic text represents a shortened version of T. Soțah 8:6-9 (Rereading the Mishnah, 109-24, quotation at 116). Smelik rejects Hauptman's theory (Rabbis, Language and Translation, 32). On the problem of the relationship between the Mishnah and the Tosefta in a more general way, see Shamma Friedman, "The Primacy of Tosefta to Mishnah in Synoptic Parallels," in Introducing Tosefta: Textual, Intratextual and Intertextual Studies, ed. Harry Fox and Tirzah Meacham (Hoboken: Ktav, 1999), 99-121.

21 This discussion is slightly more developed in the Babylonian Talmud (Soțah 35b-36a); see below, and see the discussion in Saul Lieberman, Tosefta Ki-Fshutah: Nashim, 3 (New York: The Jewish Theological Seminary, 1995), 699-702. 
R. Shimeon is close to the concise wording of the Mishnah, and makes clear that it was the Israelites themselves who transcribed the laws of the Torah in seventy languages (how they had the necessary knowledge to do so remains a mystery, but some divine revelation is probably presupposed). On the other hand, the formulation of R. Yehudah's opinion is ambiguous and could be understood to mean that the Torah was written in Hebrew, and then transcribed in the different languages of the world by the scribes of the nations themselves, who were divinely inspired to translate the text on the spot, each into his own language. Alternately, R. Yehudah could have meant that the Torah was translated into seventy languages and copied on the stones by the Israelites, and that the scribes merely transcribed the text written in their own language. ${ }^{22}$ In this case he would not differ (on this point) from R. Shimeon.

Finally, and most importantly, the purpose of the "publication" of the Torah and of the translation into seventy languages differs greatly from sage to sage. The rationale underlying $\mathrm{R}$. Yehudah's interpretation is that official knowledge of the Torah was given to the nations so that the nations could be justly condemned. ${ }^{23}$ A very important rabbinic adage states that you cannot condemn someone if he has not first been informed and warned. Hence the importance of communicating the commandments of God to the Gentiles, in order for their guilt to be clearly established. ${ }^{24}$ Rabbi Shimeon, on the contrary, leaves the possibility of the Gentiles' repentance open. This is clearly stated the end of

22 The use of the verb השיאו ("transcribed," lit. "lifted," a hiphil form of נשא) seems to support the second interpretation, but both are possible. See Marcus Jastrow, A Dictionary of the Targum, the Talmud Babli and Jerushalmi, and the Midrashic Literature (New York: Choreb, 1926), 938, who quotes this passage.

23 There seems to be a pun between the expression in Deut 27:8, "very plainly," ba'er heyțev, which the Mishnah understands as referring to the seventy languages, and the expression used by R. Yehudah who says that as soon as the nations learned about the Torah they were doomed to the "pit of destruction," be'er šahat (mentioned only once in the Bible, in Ps 55:24). The words $b a^{\prime}$ er and be'er look exactly the same.

24 See Hirshman, Torah for the Entire World, 106-7. Saul Lieberman recalls that according to a late midrash, the children of Israel could be punished for their transgressions only after the Torah had been officially published in the Tent of Meeting, and not immediately after the revelation at Sinai. He writes that some rabbinic texts "argued according to the legal practice of the Roman government. An edict had to be displayed $\delta \eta \mu o \sigma i \alpha$, in a public place; until then the people were not punishable for its transgression. Similarly, some Rabbis maintained, the Gentiles were not punishable for the transgression of the Torah until it was inscribed on the stones by Joshua. It is by virtue of the publication of the Torah on those $\sigma \tau \dot{\eta} \lambda \alpha$, that the Gentiles received their death sentence ... for its transgression" ("Appendix II: The Publication of the Torah," in Hellenism in Jewish Palestine, 2nd ed. [New York: The Jewish Theological Seminary, 1994], 201). 
the passage, which is directed at the nations: "If you repent from them (that is, from your idolatrous and immoral practices), we shall receive (or: accept) you." Therefore the translation of the Torah has, at least theoretically or ideally, a different purpose than it does in the interpretation of R. Yehudah: it creates a real opportunity for the "conversion" of the Gentiles, at least in the sense of giving up idolatry.

Rabbi Shimeon specifies that at the bottom of the altar, the Israelites wrote: "That they may not teach them [or: you, as in the Massoretic text] (to do according to all their abominable practices which they have done in the service of their gods)". This is a quotation from Deut 20:18. Deuteronomy 20 deals with the laws of war, the topic discussed at the beginning of chapter 7 of Tosefta Sotah. According to Deut 20:10-18, there is a clear difference between the wars led by the Israelites against "the cities which are very far from you," outside the Land of Canaan, to which peace can be offered (Deut 20:10-15), and those waged against "the cities of these peoples that the Lord your God gives you for an inheritance” (Deut 20:16), which must be utterly destroyed. Rabbi Shimeon's reference to a commandment pertaining specifically to the Canaanites means that the translation of the Torah was also directed at them, that they were warned of their future fate, and that they were given the possibility of repenting and being saved, instead of being put to the ban (herem). This contradicts the literal meaning of biblical passages such as Deut 20, but is indisputable in view of the sentence "If you repent from them, we shall receive you."

The view expressed by Rabbi Shimeon solves a possible ethical dilemma in connection with the Canaanites. Since, according to biblical data, they had not attacked the Israelites first, and insofar as they had not been warned that they should give up their abominable practices, their removal or destruction could seem unfair. ${ }^{25}$ The publication of the Torah in the languages of the nations, including that of the Canaanites, was meant to make them aware of the necessity of repenting from their evil ways. Once formally warned, the Canaanites had a choice, and could blame only themselves if their stubborness led to their destruction. This is, at least, the underlying logic behind this passage. ${ }^{26}$

25 See, for a comparison, how the author of the Wisdom of Salomon deals with the Canaanites (11:23-12:11). In this context too, the main issue is to justify the divine decision to dispossess and destroy them.

26 Other rabbinic texts emphasize that the Canaanites were given a choice: they could make peace with Israel, or leave, or wage war. See in particular y. Shevi 'it 6:1, 36c; Leviticus Rabbah 17:5-6. The idea that the Canaanites could have made peace with Israel is also found in the passage from Mekhilta Deuteronomy examined below (§4); see in particular note 33 . 


\subsection{Mekhilta Deuteronomy on Deuteronomy 27:8}

We find a similar logic at work in yet another tannaitic text pertaining to the issue of the Torah written on the stones after Israel's entrance into Canaan. The Mekhilta Deuteronomy is a midrash usually associated with the school of Rabbi Ishmael, which is preserved only in fragments from the Cairo Genizah or in late compilations which have added other elements to the original midrash, making it difficult to recover. Here I rely on a fragment from the Genizah and follow the edition of Menahem Kahana ${ }^{27}$ :

5 (...) On that very day Israel crossed (the Jordan), and they took the stones and carried them away 6 and erected them and they wrote on [the stones] all the words of the Torah [in the holy language (i.e., Hebrew)]. 7 R. Ishmael says: they wrote (them) in seventy languages [as it is said: very plainly (Deut 27:8)]. Rabbi 8 Shimeon ben Yohai says: They did not write (anything) upon the[m b]ut[ a copy of] the Law (Torah) of Moses, as it is said: 9 He wrote there, upon the stones, a copy of the law of Moses (etc.) (Josh 8:32). vacat R. Yose 10 ben Yosi ${ }^{28}$ says in the name of R. Eleazar ben Shimeon: They did not write upon them (anything) but what the nations 11 of the world want; for example: When you draw near to a city to fight against it, offer terms of peace to it. 12 If its answer to you is peace (and it opens to you, then all the people who are found in it shall do forced labor for you and shall serve you) (Deut 20:10-11); When you besiege a city for a long time, (making war against it in order to take it, you shall not destroy its trees etc.) (Deut 20:19). (It is) on [the stones] 13 [of the alta]r that they wrote them (the words of Torah), according to R. Yehudah. R. Shimeon said: They wrote them upon the stones (which were set up on Mount Ebal). [R. ... said:] 14 The words of R. Shimeon who said "[They wrote them] upon the stones" look (more convincing) 15 [ - as it is said: Upon] the stones (Josh 8:32) - than the words of R. Yehudah who said "They wrote them upon the

27 The translation is mine. For the Hebrew text, see Menahem Kahana, The Genizah Fragments of the Halakhic Midrashim. Part 1 (Jerusalem: The Hebrew University Magnes Press, 2005), 345, $\mathrm{n}^{\circ} 10,1.5-17$ :

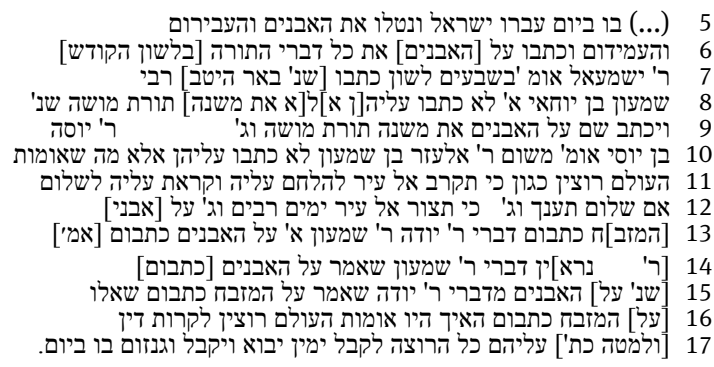

See also Lieberman, Tosefta Ki-Fshutah. Nashim. 3, 700-701; Hirshman, Torah for the Entire World, 109-10; Fraade, “The Torah Inscribed/Transcribed in Seventy Languages.”

28 Lieberman notes that this is the only reference to a tannaitic sage named in such a way (Tosefta Ki-Fshutah: Nashim, 3, 700, n. 17). 
altar." They asked: 16 They wrote them [upon] the altar? How (could) the nations of the world see ${ }^{29}$ their judgement happen? 17 [And at the bottom they wrote] on them: "Everyone who wants to make peace (lit.: receive the right [hand]), let him come and make peace.” And they hid them (the stones) on that very day.

This text shares several features with the passages from the Mishnah and the Tosefta that were examined earlier. It echoes the tradition found in the Mishnah that the Torah was written on the stones in seventy languages, and connects it with Rabbi Ishmael, known for his universalistic views. ${ }^{30}$ It also reproduces the discussion between Rabbi Yehudah and Rabbi Shimeon found in the Tosefta, but has a different version of it.

The argument is as follows: the first issue discussed by the Mekhilta, if one follows Kahana's reconstruction of the text in line 6, is language. Then comes the issue of content; and, finally, the question of whether the Torah was written on the stones of the altar or on the stones which were set up on Mount Ebal (Deut 27:4).

Concerning the first point, the issue of language, the opinion that the Torah was written on the stones in Hebrew (according to Kahana's reconstruction) is opposed by Rabbi Ishmael, who, in agreement with the Mishnah, states that the Torah was written on the stones in seventy languages. The fact that this potentially universalistic idea is attributed to Rabbi Ishmael makes sense in view of Marc Hirshman's characterization of Rabbi Ishmael's school. Rabbi Shimeon ben Yohai then argues that they wrote "a copy of the Law of Moses," mishne Torat Moshe (a reference to Joshua 8:32). This statement seems to imply that the Law of Moses was copied only in Hebrew, and not in other languages. If this reading is correct, the Mekhilta attributes to R. Shimeon a view quite opposed to the one associated with him in the Tosefta, but this would make sense coming from a disciple of Rabbi Akiva, whose positions are characterized as less universalistic than those of R. Ishmael.

After Rabbi Shimeon ben Yohai's statement comes a vacat, which may indicate that the discussion enters into a new stage. However, the repetition of the same phrase or wording by Rabbi Shimeon and Rabbi Yose, and the nature of the arguments, clearly show that their statements are connected. As a matter of fact, Rabbi Yose answers Rabbi Shimeon ben Yohai, but takes the discussion in a new direction, debating not merely the issue of language but the issue of

29 Following a correction proposed by Saul Lieberman in Tosefta Ki-Fshutah: Nashim, 3, 701 (רוצין רוצין instead רואין One could also understand," as referring to the choice the nations had to make once the divine laws were communicated to them. Still, the syntax would be odd.

30 See Hirshman, “Rabbinic Universalism”; idem, Torah for the Entire World, 109-10. 
content - which part of the Torah was written on the stones? ${ }^{31}$ In the first stage of the discussion it was stated that "all the words of the Torah" were written on the stones. According to R. Shimeon, they wrote "a copy of the Law of Moses," and Marc Hirshman interprets this as a reference to the Book of Deuteronomy alone, which is indeed a repetition or a reformulation (mishne) of the Law of Moses. For Rabbi Yose, however, it was not the entire Book of Deuteronomy that was written on the stones, but merely the commandments pertaining to the wars between Israel and the nations. The first quotation, Deut 20:10-11, refers to the rules for a war led by Israel against cities located outside Canaan, the only ones to which peace can be offered. The second quotation, Deut 20:19, is also a general rule of war, pertaining to trees: unlike human beings, trees are not enemies and should not be destroyed. One could thus conclude that Israel wrote down only the commandments pertaining to the wars against the nations that were not from Canaan. The end of the text, however, shows that the midrash actually did not follow the literal meaning of Deuteronomy 20, and understood that the offer of peace should be extended to the Canaanites as well. Therefore it is written in line 17: "Everyone who wants to make peace, let him come and make peace." "Everyone" includes the Canaanites. This radical re-interpretation of Deuteronomy 20 can be found in other rabbinic texts as well, for instance in the Jerusalem Talmud, Shevi it 6.1 (36c), in Leviticus Rabbah 17.5-6 (on Lev 14:34) or in Deuteronomy Rabbah 5.14 (on Deut 20:10), which all state that before the conquest of Canaan, Joshua sent prostagmata and offered peace to the Canaanites who wanted to make peace. ${ }^{32}$

31 Note that in the parallel discussions in the Jerusalem Talmud (Sotah 7.5 [21d]) and in the Babylonian Talmud (Sotah 35b-36a), the issue of the content of the Torah written on the stones is not debated. This point is specific to Mekhilta Deuteronomy.

32 On these rabbinic traditions, see Wilhelm Bacher, "The Supposed Inscription upon 'Joshua the Robber,' Illustrated from Jewish Sources,” Jewish Quarterly Review 3 (1891): 354-55; Victor Aptowitzer, "Les premiers possesseurs de Canaan, légendes apologétiques et exégétiques," Revue des études juives 82 (1926): 274-86; Hans (Yohanan) Lewy, "Ein Rechtsstreit um Boden Palästinas im Altertum," Monatschrift für Geschichte und Wissenschaft des Judentums 77 (1933): 84-99, 172-80; Philip S. Alexander, "The Toponymy of the Targumim, with Special Reference to the Table of the Nations and the Boundaries of the Land of Israel" (PhD diss., University of Oxford, 1974), 92-105; Katell Berthelot, "The Canaanites who 'trusted in God': an original interpretation of the fate of the Canaanites in rabbinic literature," Journal of Jewish Studies 62 (2011): 233-61; Menahem Kister, "The Fate of the Canaanites and the Despoliation of the Egyptians. Polemics among Jews, Pagans, Christians, and Gnostics: Motifs and Motives,” in The Gift of the Land and the Fate of the Canaanites in Jewish Thought, ed. Katell Berthelot, Joseph David, and Marc Hirshman (New York: Oxford University Press, 2014), 66-111. Moshe Weinfeld thought that the verses in Deut 20:10-14 were actually the original version of the tradition pertaining to Israel's interaction with the Canaanites, and that this version was reformulated later on. See Moshe Weinfeld, "The Ban on the Canaanites in the Biblical Codes," in History and Traditions of Early 
In the end, the Mekhilta argues that the possibility of making peace with Israel was communicated to the Canaanites through the revelation of at least these crucial verses of the Torah. The tragic fate of the Canaanites was the result of their rejection of the peace offered to them. The conclusion is thus similar to that of the Tosefta, except that here the focus is on peace and not on repentance. ${ }^{33}$ That the underlying question of the midrash is whether the Canaanites's fate was just or not, and therefore whether they had been warned or not, is shown by the question raised in line 17: "How (could) the nations of the world see their judgement happen?” In other words: How could they know and choose, if they were not told about the possibility of making peace?

This underlying question leads to the last issue discussed in the Mekhilta, the nature of the stones on which the Torah (or part of it) was supposed to be written. Rabbi Yehudah argues that they wrote on the stones of the altar, whereas Rabbi Shimeon seems to think that they wrote on the stones that were set up on Mount Ebal (the text is quite elliptical at these lines). In any case, the final remark that "they hid them (the stones) on that very day" makes sense only if it refers to the stones of the altar. The altar built on Mount Ebal was a temporary one, meant to be demolished after the Israelites' departure; and the stones which had been used for the altar were supposed to be hidden. ${ }^{34}$ Therefore, the problem with the fact that the words of the Torah were written on the stones of the altar was that they were displayed for a very short time only. Hence the question in line 17: "How (could) the nations of the world see their judgement happen?” (meaning: if the altar was to be demolished shortly afterwards). In the Tosefta, Rabbi Yehudah answered this question by saying that God had inspired the nations, which had sent envoys to transcribe the Torah that was written on the stones (an answer reproduced in the corresponding passage of the Jerusalem Talmud). Here this tradition seems to be implicitly presupposed, unless one wants to read the last sentence, "And they hid them (the stones) on that very day," in a cynical way, as if the information was formally published, but in such a way as to make it impossible for the nations to become aware of it. Whatever the solution imagined by the rabbis, the main point here is that the apparently superfluous discussion about the nature of the stones on which the Torah was written has to do with the underlying issue dealt with by this text

Israel, ed. André Lemaire, Supplements to Vetus Testamentum 50 (Leiden: Brill, 1993), 142-60, see 152-53; idem, The Promise of the Land: The Inheritance of the Land of Canaan by the Israelites (Berkeley: University of California Press, 1993), 96-97.

33 Peace probably implied repentance from idolatry as well, at least if the Canaanites were to stay in the country.

34 This is made clear in the discussion found in the Jerusalem Talmud, Soțah 7.5 (21d). 
(and the passage in the Tosefta), i.e., the justification for the punishment of the nations, and especially of the Canaanites.

\subsection{The Continuation of the Debate in the Two Talmuds}

The discussion of the Torah written on the stones and revealed to the nations continues in the two Talmuds. The Jerusalem Talmud (Soțah 7.5 [21d]) first raises the question of the identification of the stones on which the Torah was copied in seventy languages: were they the stones that were brought to the place where the Israelites were about to spend the night - the stones "of the lodging place" - or, rather, the stones of the altar? As mentioned previously, the problem raised by the second possibility is that this altar was not permanent; it was meant to be dismantled, and the stones were supposed to be hidden. Therefore the question arises: in such a case, how could the nations learn the Law? The answer, which in the Jerusalem Talmud is anonymous, is that God performed a miracle and "gave insight into the heart of every nation, so that they transcribed the Torah, which was written in seventy languages" (an answer similar to that of R. Yehudah in the Tosefta). Then comes the question of the plaster (sid): whereas it is easy to imagine that the stones set up as a memorial would be plastered before the Torah would be written upon them, with the altar the question arises as to whether the plaster would cover the words written on the stones. The answer, however, is that the plaster was laid only between the stones of the altar, and not on the stones themselves. Finally, the discussion concludes with a gezera shava, an exegetical technique that brings together two verses on the basis of a word or an expression that they have in common. The plaster (sid) referred to in Deut 27:2 and 4 is connected with the plaster or lime ( $\mathrm{sid}$ ) mentioned in Isa 33:12, which states that "the peoples will be as if burned to lime." In accordance with another famous exegetical principle, that of "measure for measure," the text states that because the nations refused to obey the commandments of the Torah written on the plaster, they were doomed to be burnt and turned into lime (plaster): in other terms, they will be punished in a way that recalls the nature of their sin. The passage ends with an additional "measure for measure" argument based on another biblical quotation. "The nations shall be utterly laid waste (harov yeheravu)" (Isa 60:12) leads to the statement that "from Horev comes their sentence to death": the nations shall be destroyed because they have rejected the precepts of the Torah given at Sinai/Horev.

The discussion in the Jerusalem Talmud echoes the one found in the Tosefta and in Mekhilta Deuteronomy, except that here the opinion that the Torah was 
written on the altar is attributed to R. Yose and not to R. Yehudah. As shown above, this opinion is based on the ambiguity of Deut 27 and on the wording of the Mishnah, which states that the Torah was written on the plastered stones of the altar in seventy languages. However, since the Mishnah itself also mentions the stones that were carried away to the place where the Israelites were about to spend the night, the identification of the stones comes into question. In the end, according to the discussion in the Jerusalem Talmud, either the Torah was written on the stones of the lodging place, in which case it was made easily accessible to the nations and remained so even after the departure of the children of Israel, or the Torah was made known to the nations only for a short time on the stones of the altar, making a miracle necessary in order for the nations to become aware of the Law before the latter was hidden from them. In both cases, however, the nations have had access to the content of the Law, and their refusal to live according to the precepts of the Torah shall lead to their condemnation.

Finally, in the Babylonian Talmud (Sotah 35b-36a), the discussion - which again takes place between R. Yehudah and R. Shimeon, as in the Tosefta and Mekhilta Deuteronomy - revolves around the question: was the Torah written directly on the stones or on the plaster? ${ }^{35}$ According to a literal understanding of Deut 27:3, "you shall write upon them (the stones) all the words of this Law," R. Yehudah argues that they wrote the Torah upon the stones, and plastered them with plaster only afterwards (in accordance with Deut 27:4). But then the question arises: how could the nations know the Torah if the words were covered by the plaster? R. Yehudah answers that God inspired the nations, who sent scribes who peeled off the plaster and copied the words of the Law. Consequently, the nations were doomed for having failed to follow the precepts of the Torah. R. Shimeon argues for an alternate scenario, according to which the Law was written upon the plaster, not under it. Moreover, as in the Tosefta, he specifies that the words "That they may not teach you to do according to all [their abominations]," a quotation from Deut 20:18 relating to the Canaanites, was written at the bottom of the stones. This statement is followed by the comment: "Hence you learn that if they turn in penitence, they will be accepted." The Babylonian Talmud thus roughly follows the account of the discussion found in the Tosefta, which includes the quotation of Deut 20:18 and states that the possibility of repenting was offered to the Canaanites. ${ }^{36}$ Then we find the conclusion formulated in the Jerusalem Talmud, according to which the nations will burn like

35 See the discussion by Saul Lieberman in Tosefta Ki-Fshutah: Nashim, 3, 700.

36 The Talmud simply formulates the problem in terms of "under/upon the plaster" rather than "on the stones/on the plaster." 
lime (or plaster), an idea that the Babylonian Talmud attributes to R. Yehudah. Finally, the passage goes back to the teaching of R. Shimeon, who quotes yet another biblical verse, "(When you go forth to war against your enemies, and the Lord your God gives them into your hands,) and you take them captive ..." (Deut 21:10) and teaches: "(This is) to include (lerabot, lit.: to increase or to gather) the Canaanites who reside in the Land of Israel; so that if they turn in penitence, they will be accepted." ${ }^{37}$ As in the Tosefta, Rabbi Shimeon expresses the more lenient view, that it was possible for the Canaanites to escape destruction at the hand of the Israelites, provided the former recognized the authority of the Torah and repented from their evil ways.

\subsection{Conclusion}

In conclusion, I wish to emphasize that while the texts presented here have a clear exegetical dimension, the main question underlying the admittedly obscure discussions they contain is both theological and ethical. This has to do with the fact that these texts discuss the sharing of religious Law, a particular kind of religious knowledge, and one that has special relevance because of its connection with divine judgement. The basic assumption of the rabbis was that God could punish the nations only if God's Law had first been communicated to the nations. There could be no just punishment if the Law and the punishment of the transgression had not been made known first. Without knowledge, there would be no responsibility. In this case, the possession or lack of knowledge can therefore be said to determine soteriological status, and not merely social status. The case of the Canaanites represented a particular challenge from a theological and ethical point of view, because according to Scripture their fate was particularly cruel; but the very nature of this challenge was not fundamentally different from the one raised by the confrontation between Israel and the nations in general. The main issue behind the sharing of the Torah remained the same: theodicy.

The problem faced by the rabbis did not simply originate in a kind of conflict between their ethical ideas and the content of Scripture. It was caused by their decision to envision the Torah as a Law given to Israel alone. Indeed, it was

37 Here I follow the version of MS Oxford d.20 (2675), consulted on the website of the Academy of the Hebrew Language (Ma'agarim). Other manuscripts add or substitute: "and you take them captive, to include the Canaanites who reside outside the Land [of Israel]." This is the version favored in the Soncino translation of the Talmud. 
because most of them conceived of the Torah as Israel's exclusive property, while at the same time being aware of the theological and ethical problems this raised, that they had to imagine stories about the nations who refused to live according to the Torah after having heard about its commandments. Thus the question arises: Why did most rabbis break with the idea of the Torah as a universal Law and choose to conceive of the Torah as the particular law of Israel alone? In order to answer this question, we must take into account the historical context in which the Palestinian rabbis lived.

The significance of the rabbinic texts presented here is not merely exegetical and theological; they also illustrate a wider phenomenon in rabbinic literature, i.e. the development of a counter-culture in the context of the Roman Empire where the rabbis who wrote the Mishnah, the Tosefta, the halakic midrashim and the Jerusalem Talmud lived. As Natalie Dohrmann has emphasized, the rabbis were keenly aware of the challenge posed by Roman law and the Roman legal order, and the development of the rabbinic halakic discourse may to a large extent be seen as a response to such a challenge. ${ }^{38}$ Therefore the preoccupation of the rabbis with the universal or particular character of the Torah and its theological and ethical consequences for the nations can be properly understood only if placed back into this historical context. In a world dominated by Roman law (even if other legal systems continued to function to a certain extent), most rabbis seem to have chosen the path of cultural resistance by rejecting mimetic rivalry with Roman universalism, even if a certain amount of mimicry can also be identified in the traditions examined above. ${ }^{39}$ Most rabbis embraced the notion of the Torah as the exclusive inheritance of Israel, and simultaneously chose to write down their traditions in Hebrew and Aramaic, in an idiosyncratic and elliptical style. ${ }^{40}$ In both discourse and practice, most rabbis thus favoured the path of "particularism" and hidden knowledge, which in their historical context may be seen as an expression of cultural resistance.

38 Natalie B. Dohrmann, "Law and Imperial Idioms: Rabbinic Legalism in a Roman World," in Jews, Christians and the Roman Empire: The Poetics of Power in Late Antiquity, ed. Natalie B. Dohrmann and Annette Yoshiko Reed (Philadelphia: University of Pennsylvania Press, 2012), 63-78; eadem, "Can Law be Oral? The Mixed Message of Rabbinic Oral Law," in Public and Private in Ancient Mediterranean Law and Religion, ed. Clifford Ando and Jörg Rüpke (Berlin: De Gruyter, 2015), 187-216.

39 See my forthcoming article, "Rabbinic Universalism Reconsidered.” In post-colonial studies, mimicry is described as one of the strategies adopted by subalterns in order to resist imperial or colonial domination. See for instance Leo G. Perdue and Warren Carter, Israel and Empire: A Post-Colonial History of Israel and Early Judaism (London: Bloomsbury, 2015).

40 That many Greek and Latin loan-words are found in rabbinic literature does not alter the fact that no rabbinic work is composed in Greek or Latin. 


\section{References}

Philip S. Alexander, "The Toponymy of the Targumim, with Special Reference to the Table of the Nations and the Boundaries of the Land of Israel" (PhD diss., University of Oxford, 1974).

Clifford Ando, Imperial Ideology and Provincial Loyalty in the Roman Empire (Berkeley: University of California Press, 2000).

Victor Aptowitzer, "Les premiers possesseurs de Canaan, légendes apologétiques et exégétiques," Revue des études juives 82 (1926): 274-86.

Wilhelm Bacher, "The Supposed Inscription upon 'Joshua the Robber,' Illustrated from Jewish Sources," Jewish Quarterly Review 3 (1891): 354-55.

Katell Berthelot, "The Canaanites who 'trusted in God': an original interpretation of the fate of the Canaanites in rabbinic literature," Journal of Jewish Studies 62 (2011): 233-61.

Katell Berthelot, "Rabbinic Universalism Reconsidered: The Roman Context of Some Traditions Pertaining to the Revelation of the Torah in Different Languages," forthcoming in Jewish Quarterly Review.

Herbert Danby, The Mishnah (Oxford: Oxford University Press, 1933).

Natalie B. Dohrmann, “Law and Imperial Idioms: Rabbinic Legalism in a Roman World," in Jews, Christians and the Roman Empire: The Poetics of Power in Late Antiquity, ed. Nathalie B. Dohrmann and Annette Yoshiko Reed (Philadelphia: University of Pennsylvania Press, 2012), 63-78.

Natalie B. Dohrmann, “Can Law be Oral? The Mixed Message of Rabbinic Oral Law,” in Public and Private in Ancient Mediterranean Law and Religion, ed. Clifford Ando and Jörg Rüpke (Berlin: De Gruyter, 2015), 187-216.

Steven Fraade, "Before and After Babel: Linguistic Exceptionalism and Pluralism in Early Rabbinic Literature and Jewish Antiquity," Diné Israel 28 (2011): 31*-68*.

Steven Fraade, "The Torah Inscribed/Transcribed in Seventy Languages," in Hebrew between Jews and Christians, ed. Daniel Stein Kokin, Studia Judaica 77 (Berlin: De Gruyter, forthcoming).

Shamma Friedman, "The Primacy of Tosefta to Mishnah in Synoptic Parallels," in Introducing Tosefta: Textual, Intratextual and Intertextual Studies, ed. Harry Fox and Tirzah Meacham (Hoboken: Ktav, 1999).

Sidney Greidanus, “The Universal Dimension of Law in the Hebrew Scriptures," Studies in Religion/Sciences Religieuses 14/1 (1985): 39-51.

Judith Hauptman, Rereading the Mishnah: A New Approach to Ancient Jewish Texts, Texts and Studies in Ancient Judaism 109 (Tübingen: Mohr Siebeck, 2005).

Marc (Menahem) Hirshman, Torah for the Entire World (Tel Aviv: Hakibbutz Hameuchad, 1999).

Marc (Menahem) Hirshman, "Rabbinic Universalism in the Second and Third Centuries," Harvard Theological Review 93 (2000): 101-15.

Marcus Jastrow, A Dictionary of the Targum, the Talmud Babli and Jerushalmi, and the Midrashic Literature (New York: Choreb, 1926).

Menahem Kahana, The Genizah Fragments of the Halakhic Midrashim. Part 1 (Jerusalem: The Hebrew University Magnes Press, 2005).

Menahem Kister, "The Fate of the Canaanites and the Despoliation of the Egyptians. Polemics among Jews, Pagans, Christians, and Gnostics: Motifs and Motives," in The Gift of the Land and the Fate of the Canaanites in Jewish Thought, ed. Katell Berthelot, Joseph David, and Marc Hirshman (New York: Oxford University Press, 2014), 66-111. 
Jacob Z. Lauterbach, Mekhilta de-Rabbi Ishmael: A Critical Edition, Based on the Manuscripts and Early Editions, with an English Translation, Introduction, and Notes, 2nd ed. (Philadelphia: The Jewish Publication Society, 2004).

Carlos Lévy, Cicero academicus: Recherches sur les “Académiques” et sur la philosophie cicéronienne (Rome: Ecole française de Rome, 1992).

Hans (Yohanan) Lewy, “Ein Rechtsstreit um Boden Palästinas im Altertum," Monatschrift für Geschichte und Wissenschaft des Judentums 77 (1933): 84-99, 172-80.

Saul Lieberman, Hellenism in Jewish Palestine, 2nd ed. (New York: The Jewish Theological Seminary, 1994).

Saul Lieberman, Tosefta Ki-Fshutah: Nashim, 3 (New York: The Jewish Theological Seminary, 1995).

John W. Martens, One God, One Law: Philo of Alexandria on the Mosaic and Greco-Roman Law (Boston - Leiden: Brill, 2003).

Hindy Najman, “A Written Copy of the Law of Nature: An Unthinkable Paradox?” The Studia Philonica Annual 15 (2003): 54-63.

Leo G. Perdue and Warren Carter, Israel and Empire: A Post-Colonial History of Israel and Early Judaism (London: Bloomsbury, 2015).

Fritz F. Von Schwind, Zur Frage der Publikation im römischen Recht, Münchener Beiträge zur Papyrusforschung und Antiken Rechtsgeschichte 31 (Munich: Beck, 1940).

Willem Smelik, Rabbis, Language and Translation in Late Antiquity (Cambridge: Cambridge University Press, 2013).

Gregory E. Sterling, "Universalizing the Particular: Natural Law in Second Temple Jewish Ethics," The Studia Philonica Annual 15 (2003): 64-80.

Herman L. Strack and Günter Stemberger, Introduction to the Talmud and Midrash (Minneapolis: Fortress, 1996).

Moshe Weinfeld, "The Ban on the Canaanites in the Biblical Codes," in History and Traditions of Early Israel, ed. André Lemaire, Supplements to Vetus Testamentum 50 (Leiden: Brill, 1993), 142-60.

Moshe Weinfeld, The Promise of the Land: The Inheritance of the Land of Canaan by the Israelites (Berkeley: University of California Press, 1993), 96-97. 